\title{
PERANCANGAN PROTOTIPE SISTEM PENJEJAK MATAHARI UNTUK MENGOPTIMALKAN PENYERAPAN ENERGI SURYA PADA SOLAR CELL
}

\author{
Asep Najmurrokhman dan Muhammad Fajrin \\ Jurusan Teknik Elektro \\ Universitas Jenderal Achmad Yani \\ Jl. Terusan Jend. Sudirman PO Box 148 Cimahi 40533 \\ email: asepnajmu@yahoo.com
}

\begin{abstract}
Abstrak
Energi listrik merupakan energi yang sangat dibutuhkan oleh manusia dalam melakukan aktifitas sehari-hari, sehingga menjadi bagian yang penting dalam menunjang kehidupan manusia. Energi listrik selain dapat meningkatkan kualitas hidup, juga dapat mempertinggi produktifitas usaha. Indonesia merupakan negara yang banyak memiliki pulau serta pegunungan dimana sebagian daerah-daerah tersebut merupakan daerah yang terpencil dan tidak mendapat pasokan energi listrik yang memadai. Selain itu, pasokan energi listrik tidak bisa mengimbangi kebutuhan konsumen karena kebergantungan terhadap bahan bakar minyak yang jumlahnya semakin menyusut. Di lain pihak, upaya mengurangi emisi polutan menjadi bagian dari tujuan pembangunan di abad milenium kedua ini. Untuk mengatasi hal tersebut, pemerintah berupaya melakukan program percepatan pencapaian rasio elektrifikasi pedesaan dan pemanfaatan energi terbarukan sebagai sumber energi listrik. Salahsatu bentuk energi terbarukan adalah energi matahari dan pemanfaatannya menggunakan sel surya sebagai konverter energi matahari menjadi energi listrik. Dewasa ini, masalah utama sel surya adalah efisiensi konversi energinya yang relatif masih rendah. Dalam makalah ini akan diuraikan hasil penelitian kami tentang pembuatan prototipe sistem penjejak matahari untuk mengoptimalkan penyerapan energi matahari oleh sel surya. Sistem yang dibangun tersusun oleh sensor cahaya, mikrokontroler sebagai pengendali utama, motor DC sebagai penggerak sel surya, dan panel surya. Dari hasil pengujian diamati bahwa panel surya yang disertai dengan sistem penjejak matahari memberikan keluaran energi listrik relatif lebih tinggi dibandingkan dengan panel surya yang statis.
\end{abstract}

Kata kunci: mikrokontroler, penjejak matahari, sel surya.

\section{Pendahuluan}

Energi listrik merupakan energi yang sangat dibutuhkan oleh manusia dalam melakukan aktifitas sehari-hari, energi listrik merupakan suatu bagian yang penting dalam menunjang kehidupan manusia. Listrik saat ini boleh dikatakan sebagai salah satu kebutuhan primer masyarakat, termasuk di pelosok pedesaan. Energi listrik selain dapat meningkatkan kualitas hidup, juga dapat mempertinggi produktifitas usaha yang dilakukan dimanapun.

Transaksi perbankan, proses permesinan dan produksi, televisi dan perangkat komputer merupakan komponen-komponen yang tidak dapat dilepaskan dari sumbangsih energi listrik ini dimana perangkatperangkat diatas sangat memerlukan energi listrik. Banyak yang dilakukan guna mencukupi kebutuhan energi primer ini diantaranya dengan melakukan pembangunan pembangkit-pembangkit energi listrik baik mengunakan hidro, energi fosil maupun energi angin. Ini mengingatkan kita akan pentingnya peranan energi listrik dalam kehidupan serta pendukung aktifitas dalam kehidupan sehari-hari.
Indonesia merupakan negara yang banyak memiliki pulau serta pegunungan dimana disebagian daerah-daerah tersebut merupakan daerah yang terpencil dan tidak mendapat pasokan energi listrik yang cukup maka dipandang perlu untuk mengembangkan atau memanfatkan sumber-sumber daya yang ada untuk dijadikan alternatif penyedia energi yang memiliki kemampuan untuk memasok energi listrik yang diantaranya adalah dengan pemanfaatan sel surya guna pemenuhan kebutuhan energi listrik. Sel surya merupakan piranti yang dapat mengkonversikan cahaya matahari menjadi energi listrik.

Pemanfaatan sel surya sebagai pembangkit listrik memiliki potensi yang sangat besar karena letak Indonesia yang berada didaerah tropis, yang dilewati oleh garis khatulistiwa dimana matahari bersinar sepanjang waktu, maka sangatlah tepat jika cahaya matahari ini dimanfaatkan sebagai penyedia energi listrik yang dikenal dengan Pembangkit Listrik Tenaga Surya (PLTS) atau dalam skala rumah tangga dikenal dengan Solar Home System (SHS). 
Mengingat ketersediannya matahari sepanjang tahun, maka sangatlah tepat jika energi cahaya matahari ini dimanfatkan sebagai penyedia energi listrik terutama untuk di daerah-daerah yang belum terjangkau aliran listrik. Pemanfaatan energi terbarukan khususnya energi surya mempunyai prospek yang sangat baik di Indonesia, sehingga mulai dikembangkan diseluruh pelosok daerah dengan melakukan penelitian-penelitian serta pengujian pembangkit listrik tenaga surya guna meningkatkan kinerjanya. Tabel 1 menunjukkan potensi sumber energi terbarukan di Indonesia serta jumlah pemanfaatannya yang diberikan oleh Dirjen Listrik dan Pemanfaatan Energi tahun 2001.

\section{Tabel 1. Potensi sumber energi terbarukan}

\begin{tabular}{llll}
\hline Sumber & $\begin{array}{l}\text { Potensi } \\
(\mathrm{MW})\end{array}$ & $\begin{array}{l}\text { Kapasitas } \\
\text { Terpasang } \\
(\mathrm{MW})\end{array}$ & $\begin{array}{l}\text { Pemanfaatan } \\
(\%)\end{array}$ \\
\hline $\begin{array}{l}\text { Large } \\
\text { Hidro }\end{array}$ & 75.000 & 4.200 & 5.600 \\
\hline Biomassa & 50.000 & 302 & 0,604 \\
\hline $\begin{array}{l}\text { Mini/Mikro } \\
\text { Hidro }\end{array}$ & 459 & 54 & 11,765 \\
\hline $\begin{array}{l}\text { Energi } \\
\text { Matahari }\end{array}$ & 156.489 & 5 & $3,19 \times 10^{-3}$ \\
\hline $\begin{array}{l}\text { Energi } \\
\text { Angin }\end{array}$ & 9.286 & 0,50 & $5,38 \times 10^{-3}$ \\
\hline
\end{tabular}

Dari tabel 1 dapat disimpulkan bahwa belum optimalnya pemanfaatan, pengelolaan serta eksplorasi sumber energi terbarukan seperti biomassa, energi angin, energi matahari dan yang lainnya. Matahari sebagai salah satu energi alternatif yang sangat potensial dimana potensi energi matahari ini berpotensi menghasilkan daya hingga $156.486 \mathrm{MW}$ lebih besar jika dibandingkan dengan sumber energi terbarukan yang lainnya. Jika dibandingkan dengan ketersedian energi surya maka pencapaian pemakaian ini masih sangat kecil. Energi yang dikeluarkan oleh sinar matahari sebenarnya hanya diterima oleh permukaan bumi sebesar $69 \%$ dari total energi pancaran matahari [West, 2003].

Dalam pemanfaatannya ada beberapa hal yang perlu diperhatikan guna optimalisasi energi yang akan dikonversikan, diantaranya adalah mengenai pengaruh cuaca, kelembaban, posisi sel surya serta temperatur yang terdapat pada permukaan sel surya. Cuaca, kelembaban, serta faktor debu sangat mempengaruhi cahaya yang dapat diterima oleh kolektor surya. Apabila ada yang menutupi lapisan luar alat ini maka cahaya yang akan diterima oleh semikonduktor akan berkurang dan akan berimbas secara langsung terhadap proses konversi serta efisiensi piranti tersebut akan mengalami penurunan.
Makalah ini memaparkan tentang hasil penelitian tentang pembuatan prototipe pembangkit listrik tenaga surya yang dirancang menyerap energi matahari lebih maksimal. Dalam penelitian sebelumnya [Najmurrokhman (2010)], energi cahaya yang diserap hanya sedikit yang akan berdampak pada energi listrik yang dihasilkan, karena posisi plat solar cell hanya mengarah ke satu arah dan bersifat statis, sehingga plat solar cell hanya menunggu cahaya matahari menyinari alat ini, yang berdampak langsung pada energi cahaya matahari yang didapatkan dan energi listrik yang dihasilkan solar cell. Dalam penelitian lanjutan ini, sel surya dilengkapi komponen sun tracking sehingga sel surya dapat mengikuti pergerakan matahari yang diharapkan akan mendapatkan energi listrik yang lebih banyak dibandingkan dengan sel surya yang tidak menggunakan tracking. Beberapa peneliti melaporkan hasil penelitian seputar upaya peningkatan efisiensi penerimaan cahaya matahari dan teknologi untuk meningkatkan kapasitas energi matahari yang dikonversikan menjadi energi listrik. Sarker, et al. (2010) telah merancang sistem penjejak matahari sesuai dengan arah datangnya cahaya matahari, sehingga diperoleh peningkatan energi matahari sebesar $30 \%$ yang berhasil diubah menjadi energi listrik. Karp, et al. (2010) merancang sebuah sistem konsentrator cahaya matahari sehingga diperoleh efisiensi energi matahari yang diserap untuk dikonversikan menjadi energi listrik sebesar $90 \%$. Sementara itu, Khatib, et al. (2009) merancang sebuah pengendali elektromekanik yang berfungsi menjejak cahaya matahari supaya diperoleh energi matahari yang maksimum dan berdasarkan hasil penelitiannya diperoleh energi matahari hingga $60 \%$.

\section{Perancangan Alat}

Diagram blok prototipe disajikan pada gambar 1 . Ada dua proses yang terjadi dalam sistem tersebut, yaitu tracking (penjejakan sinar matahari) dan pengisian energi listrik ke dalam baterai. Komponen utama penyusun sistem ini adalah sensor LDR, mikrokontroler, sel surya, diode, dan baterai. Saat cahaya matahari mengenai sensor LDR, motor DC akan aktif. Sensor memberi input pada mikrokontroler dan dari mikrokontroler langsung memberi perintah pada motor DC yang akan menggerakkan panel solar cell agar selalu tegak lurus terhadap arah datangnya sinar matahari. Kemudian solar cell menerima sinar matahari lalu dikonversi menjadi energi listrik oleh solar cell. Energi listrik yang dihasilkan kemudian masuk ke dioda dan dioda ini yang kemudian memberikan suplay kepada baterai. Setelah listrik masuk ke baterai hingga penuh maka baterai siap digunakan. 


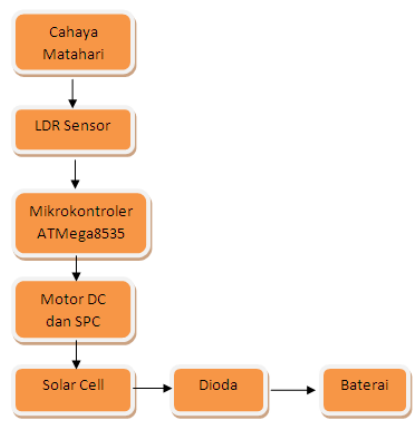

Gambar 1. Diagram blok prototipe

\subsection{Sensor LDR}

Sensor LDR adalah sebuah komponen yang nilai resistansinya berubah karena adanya cahaya yang mengenai sensor tersebut. Dalam prototipe yang dibuat terdapat 3 (tiga) buah sensor LDR yang diposisikan untuk mendeteksi arah datangnya sinar matahari dengan intensitas yang lebih tinggi. Konfigurasi dan koneksi sensor LDR dengan mikrokontroler diperlihatkan pada gambar 2 .

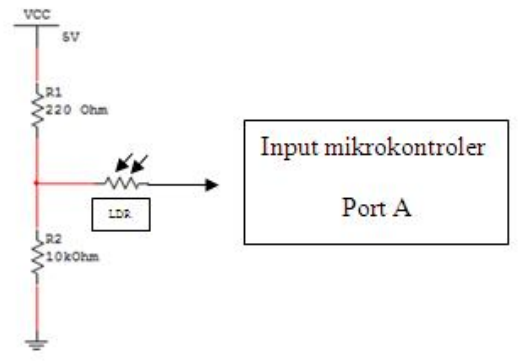

Gambar 2. Koneksi sensor - mikrokontroler

Berdasarkan spesifikasi sensor LDR yang digunakan, arus maksimum LDR adalah $30 \mathrm{~mA}$, sedangkan arus yang masuk sebesar $60 \mathrm{~mA}$. Agar tidak melebihi arus maksimum maka digunakan resistor $220 \mathrm{ohm}$. Untuk memberikan porsi arus yang lebih besar yang terkirim ke mikrokontroler, maka pada ground dipasang resistor yang lebih besar agar arus dapat mengalir pada LDR

\subsection{Mikrokontroler ATMega8535}

Dalam penelitian ini digunakan mikrokontroler ATMega8535. Sistem minimum mikrokontroler yang digunakan untuk merealisasikan alat yang dibuat diberikan pada gambar 3 .

Output dari sensor LDR diolah oleh mikrokontroler ATMega8535 dengan menggunakan bahasa pemrograman C. Garis besar program pengolah data dari sensor LDR adalah sebagai berikut:

- jika LDR A lebih besar hambatannya dari LDR B maka motor DC akan langsung otomatis aktif dan mulai bergerak searah jarum jam
- jika LDR B lebih besar dari LDR A dan LDR C maka, motor DC akan tetap bergerak searah jarum jam.

- Jika LDR C lebih besar dari LDR A dan LDR B maka motor DC bergerak berlawanan dengan arah jarum jam ke kondisi semula.

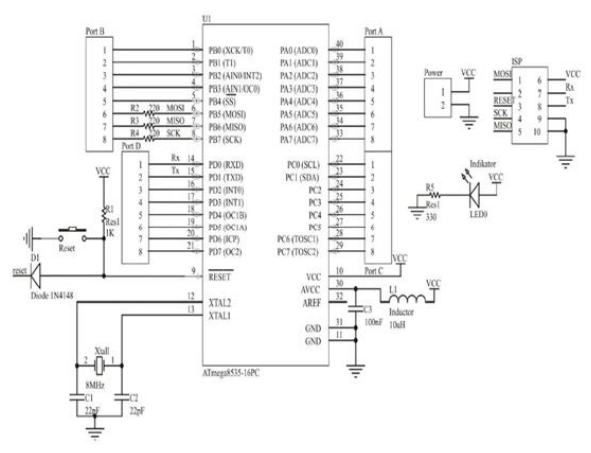

\section{Gambar 3. Sistem minimum ATMega8535}

Port yang digunakan dalam mikrokontroler ini adalah port $\mathrm{A}$ dan port $\mathrm{C}$ yang difungsikan untuk input dan Port C, serta port B untuk output. Lebih jelasnya pemakaian port pada mikrokontroler ini adalah sebagai berikut:

- Port A.0 = input sensor a

- Port A.1 = input sensor b

- Port A.2 = input sensor c

- Port C. $0=$ output

- Port C. 1 = output

Diagram alir program yang dibuat untuk merealisasikan prototipe ini diperlihatkan pada gambar 4. Pada diagram alir tersebut terlihat bahwa motor DC untuk memutar sel / panel surya bergantung kepada data yang diperoleh dari sensor yang terdeteksi oleh mikrokontroler.

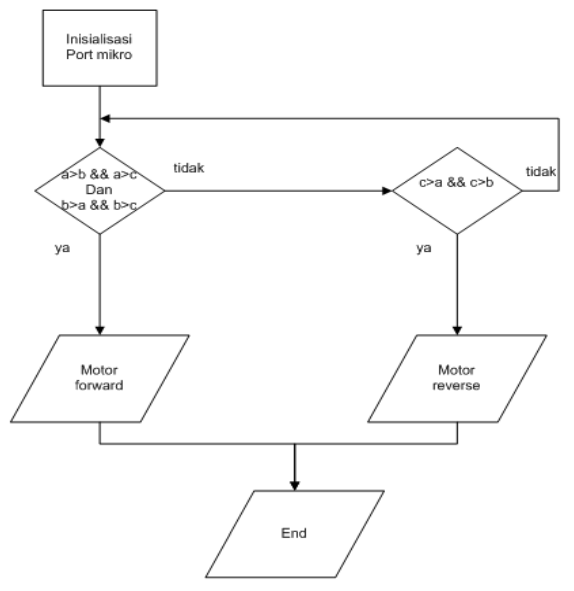

Gambar 4. Diagram alir program 


\subsection{Motor DC}

Ketika cahaya matahari menyinari sensor LDR maka mikrokontroler akan memproses output dari sensor tersebut, kemudian memberi perintah yang sesuai ke bagian driver motor DC untuk menggerakkan motor tersebut sesuai kondisi yang ditunjukkan dalam diagram alir. Rangkaian driver motor DC diperlihatkan pada gambar 5.

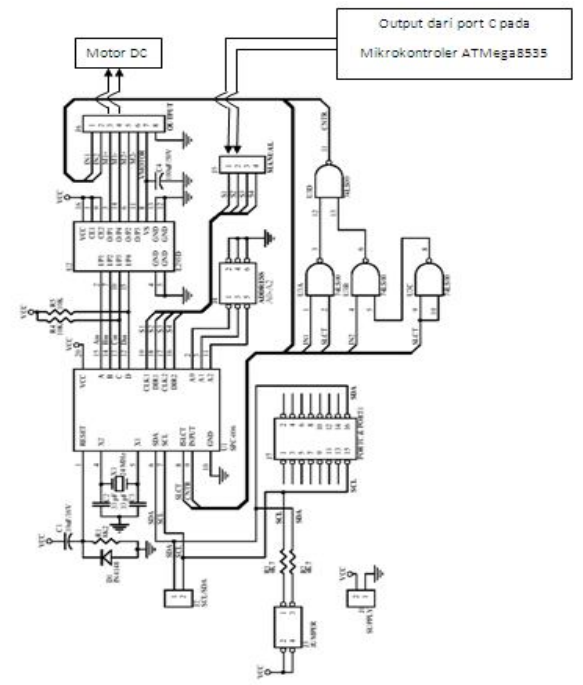

Gambar 5. Rangkaian driver motor DC

\subsection{Blok Catu Daya}

Catu daya berfungsi untuk memberikan suplai tegangan, khususnya ke IC mikrokontroler ATMega8535, catu daya yang di gunakan adalah 5 Volt dc. Untuk menurunkan tegangan trafo dari $9 \mathrm{~V}$ menjadi $5 \mathrm{~V}$ maka di gunakan IC voltage regulator LM7805. Pada rangkaian catu daya, dioda 1N4002 berfungsi sebagai penyearah gelombang penuh dari sinyal AC (bolak balik) menjadi sinyal DC (searah) dengan arus sebesar 1 Ampere, sedangkan kapasitor $50 \mu \mathrm{F}$ berfungsi sebagai filter tegangan $\mathrm{dc}$ atau penghalus pulsa-pulsa tegangan yang dihasilkan oleh dioda penyearah. Skema rangkaian catu daya di perlihatkan pada Gambar 6.

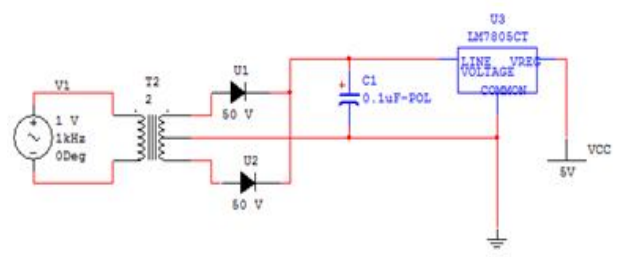

Gambar 6. Blok catu daya

\subsection{Perancangan Panel Surya / Solar Cell}

Solar cell yang dipakai pada perancangan ini adalah mini solar cell Made in China dengan ukuran
$7,5 \mathrm{~cm} \mathrm{x} \mathrm{4,5} \mathrm{cm.} \mathrm{Dalam} \mathrm{penelitian} \mathrm{digunakan} 2$ set solar cell yang dipasang paralel agar dapat menghasilkan tegangan (V) yang stabil dan menaikkan arus (I) pada saat panel surya dipanaskan oleh matahari yang terik.

Pada pengujian solar cell ini digunakan dua kondisi pada solar cell yaitu:

- Panel surya/solar cell yang dipasang tegak lurus $180^{\circ}$ (horisontal), dan

- panel surya/solar cell yang mengikuti pergerakan matahari (tracking)

Pengujian ini dilakukan agar dapat mengetahui perbedaan antara dua kondisi tersebut, khususnya untuk mengetahui perbedaan arus (I) yang didapat pada solar cell pada kedua kondisi tersebut.

\subsection{Perancangan Dioda}

Pada perancangan ini digunakan dioda 1 ampere yang dihubung seri terhadap rangkaian solar cell dan baterai. Dioda juga berpengaruh terhadap jalannya arus listrik dari panel surya / solar cell ke beban. Adapun fungsi dari dioda pada rangkaian ini adalah sebagai penahan feed back atau umpan balik arus listrik apabila tegangan berlebih pada saat panel surya dipanaskan. Penggunaan dioda agar dapat mengamankan komponen solar cell nya karena apabila terjadi feed back maka solar cell tidak akan dapat bekerja secara optimal. Arus maksimum yang bisa dihasilkan dari mini solar cell ini adalah $250 \mathrm{~mA}$ maka digunakan dioda 1 Ampere.

\subsection{Baterai}

Mini solar cell apabila terus menerus disinari oleh cahaya matahari atau dikonversikan maka akan membangkitkan arus listrik, dan arus listrik tersebut dapat disimpan pada sebuah baterai atau accumulator agar dapat dimanfaaatkan kapan saja baik malam hari maupun pada saat mendung dan matahari tidak muncul.

Dalam penelitian ini untuk penyimpan arusnya digunakan baterai dengan kapasitas tegangan (V) dan arus (I) yang kecil, karena harus disesuaikan dengan kemampuan sel surya yang digunakan yang hanya mampu mengeluarkan output maksimum 6 volt. Baterai yang digunakan untuk adalah baterai AA Energizer Rechargeable 2450 mAh 1,2V DC.

Baterai bisa digunakan pada semua alat elektronik yang menggunakan tipe baterai AA, contohnya senter, remote $\mathrm{TV}$, jam dinding dan sebagainya.

\section{Realisasi alat dan pengujiannya}

Realisasi alat diperlihatkan pada gambar 8 . Bagian paling atas dari gambar memperlihatkan panel sel surya yang dapat berputar karena adanya motor DC yang digerakkan oleh driver motor DC. Di sebelah kiri 
gambar menunjukkan sensor LDR yang berfungsi mendeteksi arah datangnya cahaya matahari sehingga bisa menentukan perputaran sel surya. Bagian kanan gambar adalah mikrokontroler sebagai pengatur utama proses pergerakkan sel surya karena cahaya matahari mengenai sensor LDR dalam prototipe ini.

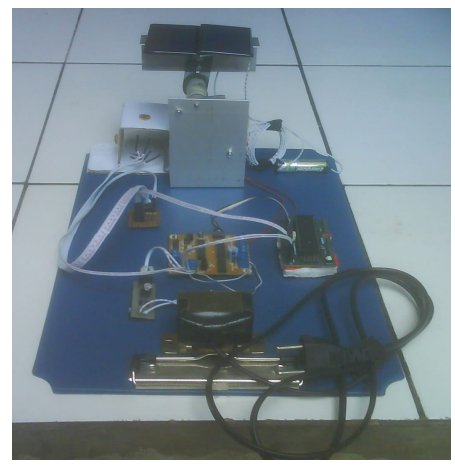

Gambar 8. Prototipe alat

Pengujian dilakukan dengan membandingkan tegangan dan arus yang dihasilkan oleh sel surya dalam keadaan statis horizontal dan menggunakan komponen tracking. Hasil pengujian diperlihatkan pada tabel 2 .

Tabel 2. Hasil pengujian

\begin{tabular}{ccccc}
\hline \multirow{2}{*}{ Jam } & \multicolumn{4}{c}{ Solar Cell } \\
\cline { 2 - 5 } & Posisi Horisontal & \multicolumn{2}{c}{ Tracking } \\
\cline { 2 - 5 } & $\mathbf{V}$ (volt) & $\mathrm{I}$ (mA) & V (volt) & I (mA) \\
\hline 07.00 & 4 & 25 & 4,2 & 45 \\
\hline 08.00 & 4,2 & 75 & 5,0 & 120 \\
\hline 09.00 & 4,5 & 125 & 5,5 & 195 \\
\hline 10.00 & 5,2 & 140 & 5,5 & 200 \\
\hline 11.00 & 5,5 & 200 & 5,6 & 220 \\
\hline 12.00 & 6,0 & 250 & 6,0 & 250 \\
\hline 13.00 & 5,8 & 215 & 6,0 & 240 \\
\hline 14.00 & 5,2 & 155 & 5,8 & 230 \\
\hline 15.00 & 5,0 & 125 & 5,5 & 200 \\
\hline 16.00 & 4,6 & 50 & 5,2 & 125 \\
\hline 17.00 & 4,2 & 20 & 5,0 & 65 \\
\hline
\end{tabular}

Dalam bentuk grafik, hasil pengujian prototipe tersebut diperlihatkan pada gambar 9. Hasil pengujan tersebut dinyatakan dalam bentuk grafik.Dalam grafik tersebut, sumbu vertikal menunjukkan arus yang dihasilkan oleh prototipe $(\mathrm{mA})$ berbanding dengan waktu. Dari data tersebut diperoleh hasil bahwa dengan bantuan tracking maka arus listrik yang di hasilkan lebih banyak dibandingkan arus listrik yang dihasilkan oleh solar cell tanpa tracking. Nilai rata-rata arus yang dihasilkan oleh sel surya statis sebesar 125,45 mA, sedangkan sel surya yang dilengkapi dengan tracking cahaya matahari sebesar 171,81 mA. Dengan demikian, konversi energi cahaya matahari menjadi energi listrik lebih optimal apabila sel surya dilengkapi dengan komponen tracking. Dengan asumsi resistansi sel surya konstan, maka sel surya yang menggunakan tracking bisa menghasilkan energi listrik $13,65 \%$ lebih banyak dibanding tanpa menggunakan tracking.

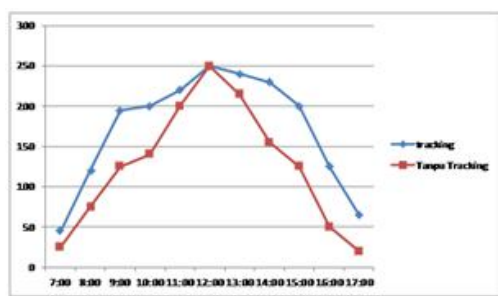

Gambar 9. Grafik nilai arus sel surya

\section{KESIMPULAN}

Dari uraian sebelumnya dapat disimpulkan beberapa hal berikut:

a. Dengan memanfaatkan energi surya sebagai sumber energi, maka dapat diperoleh pembangkit energi listrik yang bersih bebas dari berbagai polusi.

b. Pemasangan sel surya dibuat secara paralel supaya mendapatkan tegangan yang stabil serta dapat memperbesar arus yang dihasilkan oleh sel surya.

c. Sel surya dengan bantuan tracking lebih maksimal penyerapan sinar mataharinya dan energi listrik yang dihasilkan lebih banyak 13,65\% dibandingkan dengan sel surya tanpa tracking.

Sebagai tindak lanjut dari penelitian diantaranya membuat mekanisme pergerakan sel surya yang lebih dinamis menyesuaikan posisi arah datangnya cahaya matahari. Hal tersebut bisa direalisasikan dengan menempatkan sistem sensor pada bagian sel / panel surya sehingga arah jatuh cahaya matahari dengan intensitas yang lebih besar dapat diikuti terus oleh sel surya tersebut.

\section{Daftar Pustaka}

1. A. Najmurrokhman, dkk, "Prototipe Pembangkit Listrik Tenaga Matahari", Prosiding Seminar Nasional "Sains dan Teknologi dalam Penanganan Energi" , Cimahi, 25 Mei 2010, ISBN 978-979-98582-2-1, pp. $32-41$.

2. M. R. I. Sarker, Md. Riaz Pervez, and R.A Beg, Design, Fabrication and Experimental Study of a Novel TwoAxis Sun Tracker, International Journal of Mechanical \& Mechatronics Engineering IJMME-IJENS Vol. 10 No. 01, ISSN: 2077-124X, February 2010, pp. $13-18$.

3. J. H. Karp, E. J. Tremblay, and J. E. Ford, "Planar microoptic solar concentrator, Optics Express, Vol. 18, Issue 2, 2010, pp. 1122-1133.

4. K. West, Solar Cell Beyond Silicon, Riso International Energy Confrence, 2003.

5. T. T. N. Khatib, A. Mohamed, R.J. Khan and N. Amin, "A novel active sun tracking controller for photovoltaic panels”. J. Applied Sci., 9, 2009, pp. 4050 - 4055. 